\title{
¿Democracia y/o Revolución? Las Fuerzas Armadas Revolucionarias frente a la coyuntura electoral: los comicios, la revolución y la lógica instrumental (Argentina, 1972-1973)
}

\author{
Democracy and/or Revolution? The Revolutionary Armed Forces in front of the \\ electoral conjuncture: the elections, the revolution and the instrumental logic \\ (Argentina, 1972-1973)
}

\author{
Mora González Canosa*
}

\begin{abstract}
Resumen: El artículo reconstruye las prácticas y discursos políticos de las Fueras Armadas Revolucionarias durante la coyuntura electoral de 1972-1973 en Argentina. Se analizan los sentidos que le atribuyeron a su participación en la compaña electoral del peronismo, la estrategia política en que ese compromiso tuvo lugar y los cambios que dicha estrategia implicaba en relación con las posturas previas de la organización. El trabajo apela a una estrategia metodológica cualitativa sustentada en fuentes escritas y orales.
\end{abstract}

Palabras clave: peronismo, revolución, elecciones, democracia, lucha armada

\begin{abstract}
The article reconstructs the political practices and speeches of the Revolutionary Armed Forces during the electoral conjuncture of 1972-1973 in Argentina. It analyzes the meanings attributed to its participation in the electoral campaign of Peronism, the political strategy in which this commitment took place and the changes that the strategy implied in relation to the previous positions of the organization. The work appeals to a qualitative methodological strategy based on written and oral sources.
\end{abstract}

Keywords: peronism, revolution, elections, democracy, armed struggle

Recibido: 4 octubre 2017

Aceptado: 19 enero 2018

\footnotetext{
* Argentina. Doctora en Ciencias Sociales e Investigadora del Consejo Nacional de Investigaciones Científicas y Técnicas (CONICET) en el Instituto de Investigaciones en Humanidades y Ciencias Sociales (IdIHCS), Facultad de Humanidades y Ciencias de la Educación, Universidad Nacional de La Plata. Correo electrónico: gonzalezcanosa@ yahoo.com.ar.
} 


\section{Introducción $^{1}$}

Dentro del amplio espectro que va del peronismo combativo a la izquierda insurreccional, pasando por las organizaciones armadas revolucionarias de diverso signo, el proceso electoral concretado en marzo de 1973 despertó reacciones y expectativas sumamente diversas. De hecho, la estrategia aperturista de Alejandro Agustín Lanusse, quien en 1971 lanzó el Gran Acuerdo Nacional (GAN) con el objetivo de canalizar institucionalmente la protesta popular, creó serios dilemas para ese conjunto de organizaciones.

En principio, prácticamente todas ellas consideraron al GAN como una "trampa electoral" de la dictadura. Una caracterización que aunaba tanto a los que desconfiaban de su voluntad de concretar los comicios sin condicionamientos, como a quienes impugnaban al régimen por intentar encauzar el ímpetu militante de importantes sectores sociales en los marcos del sistema institucional. Sin embargo, a medida que el proceso electoral se volvía un escenario cada vez más plausible, fue imposible evitar los dilemas de la coyuntura. ¿Había que abstenerse de participar puesto que era imposible alcanzar el socialismo por vía electoral?, ¿había que impulsar los comicios y promover la radicalización del futuro gobierno democrático, desencadenando así un proceso que finalmente condujera al socialismo (nacional o a secas)?, ¿se trataba acaso de la oportunidad de que el peronismo retornara al poder tras 18 años de proscripción para cumplir sus banderas históricas?, ¿de volver a la democracia luego largos años de dictadura militar?

Ante esta encrucijada política, las posturas asumidas fueron variadas. Algunos sectores, principalmente de la izquierda insurreccional, persistieron en su rechazo a los comicios bajo consignas como "Ni golpe ni elección, revolución". Por su parte, dentro de la llamada tendencia revolucionaria del peronismo, terminaron por perfilarse dos posturas. Una de ellas, minoritaria, llamó a votar en blanco impugnando los comicios (sectores alternativistas de las Fuerzas Armadas Peronistas -FAP-). La otra, ampliamente mayoritaria, decidió apoyar la salida electoral, considerando al futuro gobierno democrático como paso previo hacia una transformación más radical de la sociedad (Barletta et. al, 2013).

Ahora bien, para el contingente militante que optó por esta última apuesta los interrogantes no terminaban allí. ¿Cuál sería el rol de las organizaciones armadas en un futuro gobierno peronista? ¿La lógica de los votos excluiría a partir de entonces la lógica de las armas? ¿Cómo garantizar el tránsito al socialismo a partir del gobierno popular? En todo caso, como ya podía intuirse, la lógica de un tipo de legitimidad basada en la legalidad democrático-institucional y la de una legitimidad revolucionaria que descreía de las

\footnotetext{
${ }^{1}$ Una versión preliminar de este texto fue discutida en la Mesa "Razón y Revolución. Radicalización política y modernización cultural (1955-1975)" de las IX Jornadas de Sociología de la UNLP, Ensenada, diciembre de 2016. Agradezco los comentarios realizados por los participantes de la Mesa, que me ayudaron a repensar el núcleo argumentativo central de este artículo.
} 
elecciones como medio efectivo para la toma del poder, ambas yuxtapuestas en esa apuesta, no tardarían en entrar en tensión (Lenci, 1999).

Considerando este marco problemático, el presente trabajo se centra en una coyuntura corta pero densa, vertiginosa y de alta incertidumbre: el contexto de apertura electoral que va de 1972 a principios de 1973, cuando la fórmula del FREJULI "Cámpora-Solano Lima" triunfó en los comicios del 11 de marzo. Y persigue, durante esos meses, los pasos de un actor particular de la tendencia revolucionaria del peronismo: las Fuerzas Armadas Revolucionarias (FAR). Nuestro objetivo es analizar las prácticas y discursos políticos de las FAR en esta coyuntura para mostrar: los sentidos que le atribuyeron a su participación en la compaña electoral del peronismo, la estrategia política más amplia en que ese compromiso tuvo lugar y los cambios que dicha estrategia implicaba en relación con la postura distintiva que había caracterizado a la organización durante 1971.

La hipótesis del artículo es que las FAR apoyaron la apertura electoral siguiendo una lógica instrumental que concebía los comicios como una táctica al servicio de una estrategia revolucionaria más amplia: construir el Ejército del pueblo que finalmente permitiría alcanzar el socialismo en Argentina. La fundamentación de dicha hipótesis nos lleva a la reconstrucción del itinerario de las FAR, mostrando los cambios y continuidades que atravesó la organización en la coyuntura electoral. Todo ello en el marco de una línea de accionar a través de la cual, como intentaremos mostrar, las FAR buscaban consolidar las fuerzas propias y avanzar en la tarea de hegemonizar el movimiento peronista.

En ese sentido, creemos que el artículo aporta conocimiento sobre una organización de la izquierda peronista que ha sido mucho menos estudiada que otras, contribuyendo de ese modo a evidenciar la heterogeneidad de estrategias, apuestas y actores que formaron parte de la tendencia revolucionaria del peronismo. Además, en contrapunto con la bibliografía que tiende a arrojar rápidamente a las tinieblas de la irracionalidad las expectativas y proyectos de este tipo de organizaciones ${ }^{2}$, nuestra intención es volverlos inteligibles, intentando comprender el sentido que los actores le atribuyeron a sus prácticas y discursos. Ese intento siempre complejo se vuelve particularmente arduo cuando, como en este caso, no sólo se trata de experiencias fallidas de las cuales conocemos su final, sino que, además, en buena medida se ha fracturado el horizonte de sentido que las guiaba.

Metodológicamente, el trabajo se basa en una estrategia cualitativa sustentada en la triangulación y análisis de fuentes documentales (diarios y revistas, documentos de las FAR y grupos políticos afines) y entrevistas orales a protagonistas.

${ }^{2}$ Nos referimos fundamentalmente a trabajos como el de Vezzetti (2009) y a otros estudios menores inspirados en su perspectiva. 
Mora González, ¿Democracia y/o Revolución? Las Fuerzas Armadas Revolucionarias frente a la coyuntura electoral: los comicios, la revolución y la lógica instrumental (Argentina, 1972-1973), Izquierdas, 38, febrero 2018:164-189

\section{Marxismo, peronismo y lucha armada: el perfil distintivo de las FAR hacia 1971}

Las FAR fueron emergente de las reconfiguraciones operadas en la cultura política de la izquierda argentina. Fundadas por grupos que rompieron con partidos de la izquierda marxista a comienzos de los sesenta (el Partido Comunista y el MIR-Praxis liderado por Silvio Frondizi), entre 1966 y 1969 participaron de distintas experiencias guevaristas. Primero viajaron a Cuba buscando sumarse a la campaña de Ernesto "Che" Guevara en Bolivia y, tras su muerte, se integraron en la sección argentina del Ejército de Liberación Nacional, que relanzó aquel proyecto bajo el liderazgo de Álvaro Inti Peredo ${ }^{3}$. Ya bajo la sigla FAR, se presentaron públicamente en 1970 con la toma de la localidad bonaerense de Garín. En 1971 asumieron al peronismo como identidad política propia desde una perspectiva marxista y un proyecto político cuyo objetivo final era el socialismo. Entre sus principales dirigentes se encontraban Carlos Olmedo, Roberto Quieto, Marcos Osatinsky, Juan Julio Roqué y Arturo Lewinger.

En ese itinerario que va desde los orígenes hasta la peronización pueden detectarse tanto cambios como continuidades. Por un lado, sus fundadores transitaron un proceso de doble ruptura respecto de los partidos donde habían iniciado su militancia en los sesenta. Tanto en términos de las formas de hacer política de aquellos partidos, que privilegiaban los métodos legales de lucha y donde la violencia figuraba como recurso de última instancia ejercido en forma masiva luego de una gran insurrección popular; como de sus tradiciones político-ideológicas, deudoras del pensamiento liberal y sumamente críticas del peronismo.

Por el otro lado, los nuevos planteos conservaron ciertas huellas de origen que le imprimieron a las concepciones y el estilo de accionar de las FAR su perfil particular. Tales huellas son especialmente perceptibles en sus posiciones de 1971, año del que datan los escritos más conocidos de la organización. Se trata de documentos ampliamente difundidos en la época y que aún hoy permanecen en la memoria de ex militantes de sectores afines: los reportajes "Los de Garín" (FAR, 1971a), las "13 preguntas a las FAR" (FAR, 1971b) y su conocida polémica con el "Ejército Revolucionario del Pueblo" (FAR, [1971] 1973). Básicamente, nos referimos al marxismo como método de análisis de la realidad nacional y como prisma de interpretación del fenómeno peronista y a la persistencia del legado guevarista como forma de pensar sus vínculos con sectores más amplios del movimiento social $^{4}$.

En cuanto a la primera huella de origen, la clave de la convergencia entre marxismo y peronismo planteada por las FAR consistió en delimitar el modo preciso en que debían entenderse ambos términos, situándolos en dimensiones diferentes. Básicamente, el marxismo fue considerado como una herramienta de análisis de la realidad nacional, es decir, negado como identidad política y situado únicamente en el lugar de la teoría. Por su

\footnotetext{
${ }^{3}$ Sobre los orígenes de las FAR pueden consultarse González Canosa (2011, 2012 y 2013b).

${ }^{4}$ Pueden encontrarse análisis específicos sobre la caracterización que las FAR hacían del peronismo y sobre la lógica de sus prácticas políticas durante 1971 en González Canosa (2015 y 2016, respectivamente).
} 
parte, el peronismo fue reivindicado como identidad política de los trabajadores, situándolo en el ámbito de la "experiencia", allí donde se hallaban los elementos de la conciencia obrera que, de ser radicalizados, podían conducir al socialismo. En definitiva, consideraban que entre peronismo y socialismo había continuidad -apuestas de radicalización, si se quiere- pero no ruptura. Aun así, las FAR asumieron el peronismo como identidad política propia de un modo crítico. Esa visión crítica sobre el peronismo tenía que ver con una clara afirmación del socialismo como objetivo final de su lucha -que la doctrina de la conciliación de clases trazada en 1945 parecía invalidar-; su aversión hacia la dirigencia sindical y política del movimiento; su profundo rechazo a toda alianza con la burguesía nacional -que el gobierno justicialista había expresado y proclamado en su doctrina- y, sobre todo, con las evidentes desconfianzas que les despertaba la figura de Perón. Sin embargo, todas esas cuestiones remitían al estado actual del peronismo, mientras que la decisión de las FAR se fundó en una apuesta por desarrollar sus potencialidades revolucionarias.

La otra huella de origen a la que hemos aludido y que también delineaba el perfil de las FAR hacia 1971, tiene que ver con la notable importancia que le atribuían al accionar armado como forma de generar conciencia entre las masas. Más allá de las semejanzas con otras organizaciones del mismo estilo, esta impronta se relaciona con los propios orígenes de las FAR, cuyos grupos fundadores habían participado de diversos proyectos guevaristas entre 1966 y 1969. Al concluir aquella etapa lo que estuvo en juego fue el pasaje desde una estrategia continental con énfasis en la guerrilla rural hacia otra de alcance nacional que terminará privilegiando la lucha urbana. Pero más allá de las discusiones sobre el alcance nacional o continental de la lucha y de su forma rural o urbana, las FAR conservaron como impronta de este itinerario las potencialidades otorgadas a la acción armada como foco irradiador de conciencia entre las masas. Desde esa perspectiva, de modo pronunciado hasta 1971 y con persistencias después, consideraban que lo central era transmitirle al movimiento popular una metodología -la lucha armada-, lo cual se lograría básicamente a través del "ejemplo" de los operativos político-militares realizados. Durante aquellos primeros años, la relación orgánica con las masas se preveía para un período posterior, luego de una fuerte consolidación interna. Y, además, creían que se lograría no tanto en base a un trabajo político de inserción en ámbitos gremiales, barriales o estudiantiles, sino a través de la atracción que generaría su accionar político-militar. La generación de vínculos orgánicos con sectores sociales más amplios comenzó a esbozarse como desafío que demandaba respuestas específicas recién avanzado el año 1971, bajo la idea de "articular" la organización político-militar con agrupaciones de activistas de base. Según las FAR, la noción de "articulación" expresaba adecuadamente el tipo de relación que, por el momento, podía plantearse entre ambas. Ello implicaba, por un lado, abandonar la idea de una fusión inmediata, lo que implicaría desconocer la diversidad de formas organizativas resultante de las tareas encaradas, que todavía exigían niveles de seguridad, recursos y militantes con formaciones distintas. Y por el otro, evitar también la división del trabajo entre unas y otras, lo que llevaría a disociar lo político de lo militar, retrasando el "alza de la militarización" que debía producirse en las organizaciones de base y convirtiendo al núcleo 
guerrillero en mero "brazo armado" del movimiento popular (FAR, 1971b: 4 y FAR [Regional Córdoba], s/f. [1971]). En cualquier caso, la noción de "articulación" remitía a una idea todavía muy general, que no planteaba grandes cambios respecto de la lógica de las prácticas político-militares las FAR, ni instancias organizativas específicas para lograr ligazones orgánicas con las masas. En consonancia con ello, y a excepción de los contactos con activistas que efectivamente comenzaban a entablarse en distintas regionales, para 1971 las FAR no habían avanzado demasiado en su tarea de "articulación".

Ahora bien, las concepciones y el estilo de accionar que caracterizaban a las FAR no permanecieron indemnes frente a la coyuntura política que terminó de delinearse hacia 1972. Para la organización, como para el resto de los grupos armados del peronismo, esa coyuntura se articuló a partir de dos factores centrales. Por un lado, el avance de las tratativas en torno a la apertura electoral, proceso a través del cual Lanusse entreveía la posibilidad de evitar la convergencia entre protesta social y política revolucionaria. Por el otro, la estrategia de Perón, quien en ese contexto impulsaba una ofensiva política tendiente tanto a la reorganización del propio movimiento como a la ampliación de sus alianzas políticas y sociales. Alianzas que excedían largamente a los sectores juveniles del movimiento y a la clase obrera, los actores que concitaban las expectativas de las organizaciones armadas. Se trata de un momento político clave para observar la reorientación de algunas posiciones de las FAR, que explican su decisión de apostar por la apertura electoral y que facilitarán su posterior fusión con Montoneros, concretada en octubre de 1973.

\section{El Gran Acuerdo Nacional lanzado por Lanusse y la ofensiva política de Perón}

Tras reemplazar a Roberto Levingston como primer mandatario de la Revolución Argentina en marzo de 1971, Alejandro Lanusse lanzó el Gran Acuerdo Nacional (GAN) planteando, aún de modo incierto, la posibilidad de una futura apertura electoral. La principal preocupación de Lanusse era evitar la convergencia entre la movilización popular y las organizaciones del peronismo radicalizado y la izquierda. En base a ese diagnóstico, su plan implicaba promover la democratización del país, canalizando institucionalmente la protesta popular para aislar políticamente a la guerrilla. Si bien sus condiciones no estaban claras, el GAN implicaba un llamamiento a deponer las antinomias volviendo a la legalidad con elecciones que incluyeran al peronismo. En su variante de máxima incluía, además, la posibilidad de que el propio Lanusse postulara su candidatura.

El proceso tenía destinatarios específicos: la dirigencia moderada del peronismo, el ala balbinista del radicalismo y las cúpulas sindicales no combativas. De ese modo, debía configurarse un campo político donde amigos (militares/aliados) y adversarios (peronismo) se enfrentarán a sus enemigos (guerrilla/sectores radicalizados), que ya no encontrarían bases de apoyo en la sociedad (de Amézola, 2000: 108).

Por cierto, la readmisión del peronismo al juego político legal, luego de largos años de proscripción, estaba sujeta a numerosas condiciones. Entre las más importantes: Perón 
no debía presentarse como candidato y tenía que desligarse de los sectores combativos del movimiento, condenando claramente a la guerrilla. Cuestión, esta última, a la que Perón se negará sistemáticamente, alentando a las organizaciones armadas en su oposición frontal a la dictadura y legitimándolas públicamente como parte del movimiento. De ese modo, el viejo general consolidaba su reaseguro ante las eventuales resistencias que surgieran de algún sector militar en contra de la consumación del proceso electoral.

Con todo, para inicios de 1972, las condiciones del GAN seguían siendo inciertas. No existían certezas de que las elecciones efectivamente se realizaran, cuáles serían sus condiciones si tenían lugar, si Lanusse lanzaría o no su propia candidatura. Sobre todo, seguía irresuelta la cuestión capital: el lugar de Perón en el futuro escenario político.

Por su parte, durante todo este período de apertura política que culminó con las elecciones de marzo de 1973, Perón siguió jugando con todas las cartas a su alcance para lograr el retorno del peronismo al poder. Desde el arte del asedio a través del impulso a la movilización popular, la legitimación de las organizaciones armadas y su propio retorno que concretará a fines de 1972; hasta las negociaciones con la dictadura y las declaraciones de tono pacificador, pasando por los ingentes esfuerzos tendientes a encauzar el propio movimiento y ampliar sus alianzas políticas y sociales.

En el marco de esta estrategia de múltiples aristas debe situarse la conformación del "Frente Cívico de Liberación Nacional" (FRECILINA), que fue lanzado a principios de 1972 y sentó las bases del "Frente Justicialista de Liberación" (FREJULI) que triunfaría en los comicios de marzo de 1973.

Siguiendo a Bozza (1999), la constitución del FRECILINA expresó la revitalización de la ofensiva política del movimiento peronista contra la dictadura, buscando convertirse en un polo de convergencia antigubernamental que permitiera ampliar las alianzas del peronismo restándole bases de apoyo a Lanusse. Con esos objetivos, supo posicionarse como herramienta tanto de negociación como de confrontación, cultivando en sus objetivos, declaraciones e iniciativas, la ambivalencia necesaria para concitar las adhesiones de actores sociales y políticos sumamente diversos.

Por un lado, si pensamos al Frente como herramienta de negociación, debe destacarse que desde su lanzamiento se propuso gestar una alianza de clases tendiente a la reconstrucción del capitalismo nacional. Es decir, un proyecto basado en el acuerdo entre el capital y el trabajo que prometía crecimiento económico, pleno empleo, desarrollo industrial y redistribución del ingreso. Bajo esa perspectiva se promovieron acuerdos con sectores del empresariado nacional representados en la Confederación General Económica (CGE) que, junto con la CGT, era uno de los pilares básicos de la alianza de clases que buscaba gestar. Al mismo tiempo, el Frente aspiraba a constituirse como una fuerza electoral que no dejaba de apelar a la "pacificación nacional", perspectiva que también signó sus alianzas interpartidarias. En ese sentido, además de realizar reuniones multipartidarias para efectuar diversas exigencias a Lanusse, el Frente incorporó en sus filas a diversos partidos provinciales, fracciones del conservadurismo popular, de la democracia cristiana, del socialismo y al Movimiento de Integración y Desarrollo (MID) liderado por Arturo Frondizi. Más que en su caudal electoral, la importancia de este último 
Mora González, ¿Democracia y/o Revolución? Las Fuerzas Armadas Revolucionarias frente a la coyuntura electoral: los comicios, la revolución y la lógica instrumental (Argentina, 1972-1973), Izquierdas, 38, febrero 2018:164-189

radicaba en su carácter de usina ideológica del desarrollismo, de donde provenían buena parte de los objetivos del Frente. A su vez, Frondizi fue una figura clave en la búsqueda de respaldos entre diversos capitales europeos, apoyos que solían presentarse ante los sectores juveniles y combativos del movimiento como expresión del sesgo antinorteamericano del Frente.

Más allá de esta ampliación de alianzas sociales y políticas, y de las negociaciones y el discurso moderado que requerían, Perón también supo instrumentar el Frente como una herramienta de confrontación tendiente a acorralar a la dictadura a través de la movilización popular. Siguiendo esa lógica, Perón aclaraba que "el proceso electoral era un medio, no un fin", por lo que advertía que el FRECILINA no debía reducirse a un "simple frente para los comicios". Desde esa tónica, lo definía como un "frente de lucha en pos de la emancipación nacional", a la que debía seguirle "la liberación de un pueblo hoy explotado". (Ollier 1989: 215). En definitiva, alentaba una concepción instrumental de los comicios donde éstos no constituían un fin en sí mismos, sino un medio para la emancipación nacional.

El discurso de la liberación nacional, que entusiasmaba a los sectores combativos del ala gremial y juvenil del peronismo y que buscaba captar también a importantes contingentes en proceso de activación externos al movimiento, signó la otra forma de acumulación política del Frente, que Bozza (1999) caracteriza como su "perfil movilizador". Una de las iniciativas claves en este sentido fue la incorporación de Julián Licastro -ex Teniente del Ejército y fundador del "Comando Tecnológico Peronista"- y Rodolfo Galimberti -líder de las Juventudes Argentinas para la Emancipación Nacional- al Consejo Superior del Movimiento Nacional Justicialista (MNJ), como representantes de su rama juvenil. El primero coordinaba las "mesas de trabajo" de las que participaban diversos grupos sociales, universitarios, culturales y técnicos proponiendo políticas de gobierno. Por su parte, Galimberti fue el encargado de poner en marcha la reorganización y unificación de las Juventudes Peronistas dando lugar, a mediados de 1972, a la conformación de la Juventud Peronista (JP) Regionales, estructura que alcanzaría una envergadura verdaderamente masiva ${ }^{5}$.

Ahora bien, tan importante como ampliar las alianzas sociales y políticas del peronismo era consolidar el frente interno, intentando encauzar las propias fuerzas del movimiento. Una tarea que excedía largamente a la organización de la juventud y que Perón encaró buscando mantener el equilibrio entre las diversas facciones del movimiento. Bajo el mandato de listas únicas, a mediados de año culminaron las elecciones internas de las autoridades del Partido Justicialista (PJ), que de ese modo lograba organizarse de acuerdo al Estatuto de los Partidos Políticos en vigencia. Perón fue elegido presidente de la cúpula partidaria, que se completó con dos vicepresidentes (Isabel y Cámpora), un

\footnotetext{
${ }^{5}$ Según indica Pozzoni (2009:176), en julio de 1972 el Consejo Superior Nacional de la JP dividió el territorio nacional en siete Regionales, cada una de ellas representada por un delegado: Regional I: Capital Federal, Buenos Aires y La Pampa (Juan Carlos Dante Gullo); Regional II: Santa Fe y Entre Ríos (Jorge Obeid); Regional III: Córdoba, Santiago del Estero y Catamarca (Miguel Ángel Mosse); Regional IV: Formosa, Chaco, Corrientes y Misiones (Guillermo Amarilla); Regional V: Salta, Jujuy, La Rioja y Tucumán (Ismael Salame); Regional VI: San Juan, Mendoza y San Luis (Luis Orellana) y Regional VII: Neuquén, Río Negro, Chubut y Santa Cruz (Hernán Ossorio).
} 
secretario general y doce secretarías repartidas de modo equilibrado entre el sector político, femenino, sindical y juvenil, lo que generó resistencias de la rama gremial, que exigía mayores cuotas de poder dentro del aparato partidario. Con todo, el general también logrará, aunque de modo precario, apaciguar el descontento de la dirigencia sindical tradicional y su disposición a negociar en forma autónoma con el gobierno ${ }^{6}$. Para la alianza de clases que el Frente buscaba gestar, la reunificación sindical resultaba clave, por lo que hacia mediados de año Perón legitimó a las autoridades de la CGT y a los referentes de la "62 organizaciones" -la llamada "burocracia sindical"- instando a todas las tendencias gremiales a acatar sus decisiones. Ese tipo de políticas compensatorias y los variados roles que Perón le asignaba a los distintos sectores del peronismo dentro de una estrategia sumamente flexible, signaron toda la reorganización de la estructura del movimiento. Ello explica que, al mismo tiempo que el general alentaba a la juventud y avalaba a las organizaciones armadas, incorporaba al Consejo Superior del MNJ a una figura de la ultraderecha peronista como el teniente coronel Jorge Osinde. Si la juventud encarnaba la estrategia de confrontación con el gobierno, el oscuro oficial de inteligencia era uno de los encargados de los contactos con las FFAA, a través de los cuales Perón buscaba aislar a Lanusse del conjunto de la institución castrense. Por su parte, el nombramiento de Juan Manuel Abal Medina como secretario general del MNJ, efectuado meses después, condensaba la intención del general de mantener unidas las disímiles vertientes de su movimiento. Su apellido lo ligaba a Montoneros, aunque su principal virtud era que a ello podía sumarle sus contactos con un sector de la oficialidad de las FFAA y también de la dirigencia sindical encabezada por Lorenzo Miguel y José Ignacio Rucci.

Paralelamente a los avances que se lograban en términos de la reorganización del peronismo y el armado de nuevas alianzas políticas y sociales, a mediados de 1972 el duelo entre Perón y Lanusse alcanzó un punto de inflexión y el diálogo entre ambos generales dio paso a una etapa de desafío abierto. En julio, Perón divulgó una serie de conversaciones mantenidas con emisarios de Lanusse que la Junta de Comandantes desconocía, generando un conflicto en la interna militar. Por su parte, Lanusse hizo públicas las reglas de la apertura electoral fijada para marzo de 1973, incorporando una cláusula por la cual se le prohibía presentar candidaturas a quienes no permanecieran en el país desde el 25 de agosto hasta los comicios, como también, a aquellos que desempeñaran cargos públicos después de esa fecha. De esta forma, Lanusse conseguía la proscripción de Perón como candidato presidencial -se descontaba que el general no aceptaría el condicionamiento- y aquietaba la interna militar, auto proscribiéndose como posible candidato. A partir de allí, la JP Regionales convocará movilizaciones multitudinarias bajo la consigna "Luche y Vuelve" y se anunciará el retorno de Perón, que se concretará en noviembre.

\footnotetext{
${ }^{6}$ Hacia 1972 podían reconocerse cuatro tendencias dentro del mapa gremial peronista: 1) la "Corriente de Opinión" conocida como "participacionismo"-, donde se destacaba la figura de Rogelio Coria; 2) la vertiente de confrontaciónnegociación, principal heredera del vandorismo y nucleada alrededor de la UOM liderada por José Ignacio Rucci y los grandes sindicatos; 3) el "grupo de los 8", un desprendimiento temporal del vandorismo que se había opuesto a la reelección de Rucci en la conducción de la CGT y, distantes de esas tres tendencias que no tenían antagonismos irreductibles entre sí 4) los gremios enrolados en el denominado peronismo gremial "combativo" (Bozza, 1999: 139).
} 
¿Cuál fue la posición de las FAR en la nueva coyuntura atravesada por la cuestión electoral? Recordemos que la organización se había gestado bajo la convicción de que era imposible alcanzar el socialismo a través de medios pacíficos y que ni el triunfo en las urnas de la Unidad Popular ni el posterior gobierno de Salvador Allende la habían convencido de una posible "vía chilena" al socialismo. De hecho, en principio se entusiasmaron con la etapa de confrontación abierta entre Perón y Lanusse que se desató en julio, considerando que implicaba el "hundimiento" del GAN como "trampa del régimen". Según sostenían en sus documentos de esos meses, Perón había desbaratado "la maniobra integracionista del enemigo", consistente en "incorporar a la masa peronista al sistema institucional burgués". De ese modo, afirmaban, el viejo general impedía el "aislamiento" de las organizaciones armadas y posibilitaba su "sólido desarrollo en un fértil terreno político". En ese contexto, la organización podría seguir cumpliendo su "papel de foco en el marco del peronismo", lo cual contribuía a generar "organización y condiciones revolucionarias en el MNJ" (FAR, 1972a) ${ }^{7}$. Es decir que, si durante sus primeros años las FAR concebían el accionar armado como foco irradiador de conciencia entre las masas, ahora consideraban que la eventual clausura de la perspectiva electoral les permitiría continuar ejerciendo ese rol de foco concientizador pero en el marco específico del movimiento peronista. Como puede verse, más allá de las controversias sobre la candidatura de Perón, la apertura electoral no aparecía en lo absoluto como un escenario deseable para la propia estrategia de la organización.

Con todo, el avance de las tratativas en torno a la apertura electoral, la ofensiva política de Perón y las posibilidades ciertas de que el peronismo se integrara en el "sistema" terminaron por imponer uno de los mayores desafíos que experimentaron las FAR: cómo ampliar sus bases de apoyo para evitar el aislamiento respecto del peronismo y el movimiento social más amplio al que parecía conducirlas la nueva coyuntura. Un desafío al que la organización no respondió sólo con la inercia de las posiciones previas.

\section{El reposicionamiento de las FAR en la coyuntura preelectoral del año 1972: la necesidad de consolidar las fuerzas propias}

Tres fueron las líneas de acción que esbozaron las FAR para tratar de consolidar las fuerzas propias y reposicionarse en la encrucijada política que terminó por delinearse en 1972. 1) La realización de acciones armadas, tanto de pequeña como de gran envergadura, que continuaron aún en el contexto preelectoral -piénsese en la fuga del penal de Rawson de la que participaron en agosto-. 2) Avanzar en la convergencia con otras organizaciones armadas peronistas. Se trata de una perspectiva que, tras el fallido intento de crear una instancia de coordinación entre todas ellas (las llamadas "Organizaciones Armadas Peronistas"-OAP-) y de distanciarse de la propuesta "alternativista" que por entonces

\footnotetext{
${ }^{7}$ El documento en cuestión se titula "Documento de Actualización Política” y está fechado en el mes de septiembre.
} 
Mora González, ¿Democracia y/o Revolución? Las Fuerzas Armadas Revolucionarias frente a la coyuntura electoral: los comicios, la revolución y la lógica instrumental (Argentina, 1972-1973), Izquierdas, 38, febrero 2018:164-189

perfilaba parte de las $\mathrm{FAP}^{8}$, derivó en un largo proceso de acercamiento y fusión con Montoneros. Y, finalmente, 3) consolidar vínculos más orgánicos con sectores combativos del movimiento popular.

En consonancia con esta última línea de acción, y en relación con el desafío que se habían planteado a fines de 1971, durante todo el año 1972 las FAR realizaron avances significativos en términos de su política de articulación con agrupaciones de activistas, principalmente a nivel estudiantil y barrial, en sus diversas regionales (sobre todo Buenos Aires, Córdoba, Tucumán y luego en Santa Fe y Mendoza). A su vez, también se propusieron gestar una estructura organizativa intermedia entre el nivel de militancia armado y no armado. Se trató de los denominados "comandos de apoyo", tal como Montoneros había hecho lo propio con las llamadas 'Unidades Básicas Revolucionarias' (UBR) ya en 1971. Sin embargo, a diferencia de las UBR, que buscaban convertirse en "conducción táctica" de la movilización popular, la función que las FAR le atribuían a estos comandos era básicamente contribuir al fortalecimiento de la organización armada a partir del apoyo logístico y la realización de operativos de poca envergadura (FAR, 1972a). Además, según los testimonios, tampoco parecen haber tenido una realidad práctica muy extendida.

También en el marco de la última línea de acción señalada debe ubicarse la decisión de las FAR de apoyar al peronismo en las elecciones si estas finalmente se realizaban y los sentidos que le atribuyeron a dicho compromiso. De hecho, a mediados de 1972 y aún con las expectativas puestas en el "hundimiento" del GAN, también preveían la eventual participación del peronismo en los comicios y se posicionaban frente al tema como ya había hecho Montoneros. Como señalaban en un documento donde intentaban consensuar posturas con dirigentes montoneros presos en el penal de Rawson, en ese escenario, dado que el pueblo no estaba preparado aún para rechazar las elecciones -lo cual, se infiere, hubiese sido deseable-, éstas debían ser utilizadas para ampliar las fuerzas propias y debilitar al enemigo. La idea era convertir la coyuntura electoral en un "elemento concientizador" y que el período de funcionamiento de la "democracia liberal" sirviera para demostrar que ese no era el camino para resolver los problemas fundamentales del pueblo. Como, también, para poner en evidencia el "carácter burgués y las limitaciones de la superestructura político-gremial del Movimiento". En definitiva, debía ser utilizada como una táctica en función de sus propios objetivos estratégicos: construir el Ejército del pueblo que condujera una guerra popular y prolongada en pos del socialismo (FAR y Montoneros,

8 La postura "alternativista" mantenía la identidad peronista pero impulsaba, desde una posición clasista, la construcción de una herramienta política autónoma para los trabajadores. En consonancia con esa línea, planteaban al socialismo como objetivo final, la existencia de contradicciones de clase al interior del movimiento peronista, a los trabajadores como único sujeto revolucionario y la imposibilidad de alianzas con la burguesía nacional. A su vez, el sector "alternativista" de las FAP se proponía reorientar su práctica hacia el trabajo de base, rechazaba toda participación en las estructuras formales del movimiento -inclusive las sindicales-, y se oponía a la participación del peronismo en los comicios. Finalmente, si bien no se lo planteaba abiertamente, los testimonios indican que Perón ya no era concebido como un líder revolucionario, aunque podría conducir al menos parte del proceso de liberación nacional en la marcha al socialismo. (Raimundo, 2004). 
Mora González, ¿Democracia y/o Revolución? Las Fuerzas Armadas Revolucionarias frente a la coyuntura electoral: los comicios, la revolución y la lógica instrumental (Argentina, 1972-1973), Izquierdas, 38, febrero 2018:164-189

1972) ${ }^{9}$. Con el correr de los meses, el término más usual para aludir a esa lucha que debía darse en "todos los terrenos", desde la acción armada hasta la participación electoral, será el de "guerra integral", tomado del léxico aggiornado del viejo general. Como veremos más adelante, aún durante la campaña electoral del verano de 1973 las FAR siguieron considerando su apoyo a los comicios como una táctica al servicio de una estrategia más amplia.

A estas líneas de acción para reposicionarse en la nueva coyuntura hay que sumar dos cambios sustantivos en la postura de las FAR que, además, facilitarán su acercamiento a Montoneros. Nos referimos a su cambio de política hacia las llamadas "estructuras formales" del movimiento peronista (políticas y sindicales) y a sus nuevas consideraciones sobre la alianza de clases trazadas por Perón en el marco del FRECILINA.

En consonancia con planteos previos, las FAR consideraban que el peronismo era un movimiento de masas policlasista cuyo eje central era la clase obrera. En base a ello, argumentaban que el movimiento sintetizaba todos los avances y limitaciones de la conciencia política y los métodos de lucha de la clase obrera como, también, las contradicciones de las distintas fuerzas que lo integraban. Por su parte, el Movimiento Nacional Justicialista (MNJ) -que consideraban compuesto tanto por sus "estructuras legales" como por las organizaciones armadas peronistas- era la estructura organizativa que expresaba al movimiento a nivel de su lucha por el poder político, por lo que sus formas ideológicas y organizativas sintetizaban también las contradicciones antes mencionadas. Desde esas claves, afirmaban que la historia interna del MNJ debía verse como el derrotero de la lucha de la clase obrera peronista por construir los "instrumentos ideológicos y organizativos" capaces de expresar sus "intereses objetivos en el nivel de la lucha política". Esto es, la "historia de las sucesivas etapas hacia la construcción de un instrumento específico y autónomo de poder de la clase obrera peronista, en el marco de las estructuras políticas del movimiento" (FAR, 1972a, el subrayado es nuestro). Frente a dicha formulación, donde pese a situar tal instrumento "autónomo" en el "marco" del movimiento podía resonar la postura "alternativista" de un sector de las FAP, las FAR se distanciaban de lo que llamaban el "purismo clasista". La presencia masiva de la clase obrera peronista hacía del movimiento -y también del MNJ, aclaraban-, el instrumento político más efectivo de oposición a los intereses del "polo oligárquico-imperialista". A su vez, el desarrollo de esa estrategia de oposición conducida por Perón -acotaban-, agudizaba las contradicciones internas del MNJ, que eran el motor de la progresiva constitución autónoma de los trabajadores frente a las otras clases que integraban el movimiento. De ese modo, y en sintonía con posiciones previas, las FAR sostenían que su objetivo era lograr la hegemonía de los "intereses históricos" de la clase obrera dentro del peronismo.

\footnotetext{
${ }^{9}$ Este documento, titulado "Opiniones sobre los problemas centrales de la guerra revolucionaria en esta etapa", se conoció como el "Balido de Rawson" y fue escrito en la cárcel patagónica de modo conjunto por dirigentes de FAR y Montoneros poco antes de la fuga del 15 de agosto de 1972. Allí, los dirigentes presos de ambas organizaciones intentaron plasmar sus principales coincidencias políticas como aporte para un proceso de fusión cuya concreción avizoraban cercana.
} 
Ahora bien, a tono con la renovada importancia que adquirían las estructuras institucionales del peronismo en el marco de la reorganización impulsada por Perón y con la postura "tendencista" de Montoneros a la que se acercaban ${ }^{10}$, pueden rastrearse cambios importantes en las consideraciones de las FAR sobre las estructuras del MNJ. De hecho, aparece un matiz inexistente en sus documentos del año 1971: la distinción entre tales estructuras en sí mismas y los dirigentes que representaban la "táctica integracionista y conciliadora del enemigo" dentro del MNJ. Ahora planteaban que como organización armada no tenían "contradicciones antagónicas" con dichas estructuras en sí mismas, puesto que, instrumentadas por Perón en el marco de una estrategia de conjunto, servían para enfrentar al enemigo en el terreno de la "institucionalidad burguesa". Por ello, sólo debían negarse cuando ya no sirvieran a ningún "objetivo táctico" (FAR, 1972a). Respecto de la política a darse con ellas, seguían sosteniendo que la "superestructura" política y sindical del movimiento, dado que se movía en el marco de las normas legales del régimen, no era una herramienta apta para conducir el proceso revolucionario. El objetivo central continuaba siendo la creación del Ejército popular y la integración del pueblo en los organismos que lo iban construyendo (las organizaciones armadas, los niveles intermedios "comandos de apoyo" en las FAR, UBR en Montoneros- y las agrupaciones de base). Sin embargo, afirmaban junto a Montoneros que eso no significaba evitar la militancia en dichas estructuras, pues lo importante no era el "lugar donde se lleva[ba] a cabo un trabajo" sino la "política que se impulsa[ba]" (FAR y Montoneros, 1972). Según las FAR, con quienes sí tenían "contradicciones antagónicas" era con buena parte de la "burocracia sindical y política" que ocupaba tales estructuras. Más allá de la "justicia popular” que pudiera caberles a algunos de ellos -advertían-, el objetivo era aislarlos, restarles apoyos dentro de las propias estructuras que les daban base de sustentación (FAR, 1972a).

En consonancia con esa perspectiva, ya en sus comunicados de abril de 1972 las FAR proclamaban que las organizaciones armadas y de base, sin desviarse de su estrategia de guerra popular y prolongada, debían "dar batalla en todos los frentes y en todos los terrenos", yendo a "todos los centros de movilización para expulsar del movimiento a los traidores” (FAR, “Comando Eva Perón”, 1972). Es decir que, al igual que Montoneros, ya no rechazaban impulsar la movilización a partir de las estructuras del peronismo sino que buscaban hegemonizarlas, quitándoles base de sustentación a sus dirigentes. Con el correr de los meses esta política se expresó tanto en la militancia territorial que comenzaron a desarrollar en Unidades Básicas del movimiento como en el envío de comunicados y la

10 Siguiendo a Lanusse, podemos caracterizar la postura de Montoneros situándola entre dos extremos polares: el "alternativismo" y el "movimientismo". Según el autor, esta tercera postura, que denomina "tendencista", sostenía que dentro del movimiento peronista existían diferencias irreconciliables, aunque se le atribuían potencialidades revolucionarias y se llamaba a dar el combate en su interior. La idea era conformar una "tendencia revolucionaria" que representara los intereses de la clase obrera y hegemonizara el movimiento, transformándolo en una herramienta política capaz de producir cambios radicales. De allí que, a diferencia de la postura "alternativista" de un sector de las FAP, no se rechazara de plano la participación en las estructuras formales del peronismo. En esta visión, los "burócratas" eran considerados enemigos, aunque se toleraba la convivencia "táctica" con ellos. A su vez, se asumía que, si Perón no era un líder cabalmente revolucionario, se volcaría hacia esa postura si la "tendencia" lograba hegemonizar el movimiento. (Lanusse, 2005: 255-256). 
Mora González, ¿Democracia y/o Revolución? Las Fuerzas Armadas Revolucionarias frente a la coyuntura electoral: los comicios, la revolución y la lógica instrumental (Argentina, 1972-1973), Izquierdas, 38, febrero 2018:164-189

participación en las multitudinarias manifestaciones organizadas por la JP Regionales durante el segundo semestre de 1972 (FAR, 1972b).

Por último, respecto de la alianza de clases trazada por Perón en el marco del FRECILINA, las FAR afirmaban que constituía tanto una maniobra táctica de Perón para aislar a la dictadura como, también, una propuesta estratégica para nuclear en torno al MNJ a todos los sectores "dispuestos a luchar por la liberación nacional y social”. En términos del respaldo buscado entre los capitales europeos, lo atribuían a una maniobra espuria del "tándem Frondizi-Frigerio", cuyo objetivo era utilizar la base social del peronismo para un proyecto de desarrollo capitalista dependiente de una nueva metrópoli (FAR, 1972a). Por el contrario, en su escrito conjunto con Montoneros, lo planteaban como una iniciativa más de Perón para aislar a Lanusse y a la "fracción hegemónica de las clases dominantes" que éste representaba, aprovechando las contradicciones internas de la "burguesía monopolista" (FAR y Montoneros, 1972). Más allá del debate sobre los capitales europeos, frente al nuevo esquema de alianzas trazado por Perón los planteos de las FAR introducen un cambio notable respecto de sus escritos del año 1971: su mayor predisposición a aceptar la existencia de contradicciones internas en la burguesía nacional. Ahora sostenían que si bien la burguesía industrial había sido "casi" totalmente absorbida por la burguesía monopolista, existían "algunos sectores de la burguesía" y "grandes sectores de la pequeña burguesía" cuyos intereses sólo podían satisfacerse junto con los de la clase obrera (FAR, 1972a). Con ello, las FAR dejaban atrás uno de los tópicos centrales que había marcado el derrotero de sus grupos fundadores y la perspectiva de la organización durante sus dos primeros años. En la nueva coyuntura política, la convergencia con sectores de la burguesía se consideraba viable al menos durante cierto tramo del proceso de liberación nacional y social que impulsaban. Paradójicamente o no, respecto de este punto la postura de las FAR ya no se encontraba tan distante de la del PC, partido en el que habían iniciado su militancia parte de sus fundadores.

De todos modos, la apuesta central de las FAR tanto en el marco del MNJ como del FRECILINA era otra. Según la organización:

Nuestro papel es el de confluir y articularnos con todos los sectores del peronismo que desarrollan la guerra de liberación para expresar los intereses de la clase obrera, tanto en el campo ideológico como en el organizativo. La organización resultante de ese proceso será el instrumento que ha de constituirse en pilar hegemónico del MNJ, y, por ende, del FCLN. Sólo así contribuiremos a construir un arma integral para la guerra de liberación. (FAR, 1972a, el subrayado es nuestro).

Decididamente en coincidencia con la postura "tendencista" de Montoneros y sin reparos frente al hecho de que el movimiento contara ya con un partido (el PJ), la apuesta por hegemonizar tanto el MNJ como el FRECILINA es clara. Ante la nueva coyuntura, donde la organización corría el riesgo de quedar aislada frente a la importancia que adquirían las estructuras formales del peronismo, se tornaba acuciante consolidar las fuerzas propias para hegemonizar el movimiento. Si bien la intención de ligarse con sectores sociales más amplios siempre estuvo en el proyecto de las FAR, es en el marco de 
esta encrucijada política, signada tanto por la apertura electoral como por la puja de poder dentro del movimiento, donde también debe ubicarse el carácter estratégico y la premura que adquirió su "articulación" con "organizaciones de base" y la militancia territorial en Unidades Básicas. Su acercamiento y futura fusión con Montoneros también llevaba inscripta esa lógica.

Ahora bien, tan importante como analizar los posicionamientos de las FAR ante las iniciativas de Perón, resulta abordar los planteos que hacían sobre el propio general en esta nueva coyuntura signada por un tiempo político vertiginoso.

\section{Perón: un líder popular y transitorio...}

Durante estos meses del segundo semestre de 1972 en que Perón estaba en el centro de la escena pública, se observan en los documentos de las FAR todas las ambivalencias y tensiones que concitaba su figura. Por un lado, en sus escritos y comunicados reconocían de modo entusiasta su liderazgo, al tiempo que varios entrevistados recuerdan -con cierta perplejidad retrospectiva- los arrebatos de fervor en favor del general que experimentaban sobre todo durante las movilizaciones desatadas a partir de su primer retorno. Pero, por otro lado, las FAR reivindicaban abiertamente su autonomía para definir la estrategia y métodos de lucha de la organización, lo cual auguraba futuras tensiones con Perón. A su vez, le dirigían una serie de críticas apenas matizadas con el argumento de que el general sintetizaba el grado de conciencia alcanzado hasta el momento por el pueblo.

La afirmación de independencia para definir sus propios objetivos y la línea de su accionar es explícita en "Documento de Actualización Política" (FAR, 1972a). Allí, las FAR proclamaban que como "estructura integrante del MNJ", la organización "reivindica[ba] su autonomía en lo que hac[ía] a la elaboración política y estratégica", que definían con "total independencia de juicio". Y, conscientes de la tensión que ello sugería, aclaraban que no existía ninguna incompatibilidad entre esa pretensión y su reconocimiento de la conducción estratégica de Perón. Para justificarlo, apelaban a interpretaciones sobre las posiciones del general disponibles en la tradición del peronismo de izquierda. Interpretaciones donde, básicamente, Perón aparecía como un líder despojado de voluntad política propia, obligado a moverse en el "campo del sistema" con los recursos a su disposición (la "superestructura política y sindical" del movimiento), lo cual volvía necesario que las fuerzas revolucionarias gestaran una alternativa por la que finalmente pudiera optar.

Más allá de esa fuerte declaración de autonomía, es en el "Balido de Rawson", el escrito en que dirigentes de FAR y Montoneros buscaban consensuar posturas con vistas a la fusión, donde más se profundiza en la caracterización del rol de Perón. Allí se realizaban una serie de observaciones críticas que sorprenden por el carácter explícito de su formulación. En principio, se advertía que debía evitarse tanto la mistificación como la negación de su figura, de las que se derivaría su calificación como "líder revolucionario" o bien como "líder burgués". Por el contrario, en el escrito se afirmaba que Perón era un líder popular (FAR y Montoneros, 1972). Efectivamente, según los testimonios, esa era la 
caracterización que las FAR hacían del general: un "líder popular" capaz de conducir ciertos tramos del proceso de liberación, pero no un "líder revolucionario" (entrevista a Jorge Lewinger). Mientras tanto, Fernando Vaca Narvaja, quien participó de la redacción del documento junto a Roberto Quieto y Marcos Osatinsky de las FAR, aclara que el escrito fue criticado por la dirigencia montonera que no se encontraba en el penal de Rawson justamente porque calificaba a Perón como líder popular y no como un líder revolucionario (Vaca Narvaja y Frugoni, 2002: 130) ${ }^{11}$. En el mismo sentido, Lewinger sostiene que esa distinta valoración del liderazgo del general era uno de los principales puntos de fricción entre ambas organizaciones fuera de la cárcel.

La argumentación que sostenía dicha valoración de Perón no era menos controversial que la caracterización misma. Partía de las clásicas interpretaciones de la izquierda peronista para quien el general estaba constreñido a la utilización táctica de las estructuras institucionales de su movimiento, por lo que había que brindarle una nueva alternativa revolucionaria que pudiera elegir. Sin embargo, a las limitaciones señaladas, FAR y los dirigentes montoneros presos les sumaban otras: "sus fallas en lo ideológico y su poco clara adhesión a una sólida estrategia de poder", una afirmación apenas compensada con la aclaración de que tales falencias expresaban las "limitaciones generales del Movimiento" (FAR y Montoneros, 1972). A su vez, las consideraciones del "Balido" daban un paso más. Se afirmaba que la relación establecida entre el líder y las masas correspondía a un "primer plano de la conciencia" del pueblo. Perón unificaba las voluntades de las masas y sintetizaba políticamente sus avances, pero ese tipo de relación correspondía a una primera etapa del movimiento, cuando el nivel de conciencia del pueblo no había producido aún una herramienta político-militar que lo organizara para la toma del poder. Mientras tanto, la relación que se establecería entre la futura vanguardia y las masas implicaba un "salto cualitativo" que se daría en un "plano superior de conciencia", propio de la etapa de la guerra popular prolongada. Por si no quedaba claro que el liderazgo de Perón era considerado transitorio y que debía ser reemplazado por el de las organizaciones armadas, FAR y los dirigentes presos de Montoneros explicitaban:

Pero ¿hay una oposición entre el accionar de Perón y el de nosotros, gérmenes de esa futura vanguardia? No, el grado de conciencia actual alcanzado por el pueblo se expresa en su relación con el líder que, como Perón, sintetiza sus esfuerzos. Paralelamente a ello va surgiendo y consolidándose su vanguardia: el EPM [Ejército Peronista Montonero], que va planteando formas de organización superiores, acordes con mayores

\footnotetext{
${ }^{11}$ Por lo dicho, parece claro que al menos respecto de la valoración de la figura de Perón, las consideraciones del "Balido de Rawson" son más representativas del pensamiento de las FAR que de Montoneros. Además de los dirigentes mencionados, es probable que participaran de su redacción los militantes de mayor jerarquía de ambas organizaciones que estaban detenidos en Rawson. Ellos eran Alberto Camps, Alfredo Kohon, Carlos Astudillo, María Angélica Sabelli y María Antonia Berger por las FAR, y Mariano Pujadas, Susana Lesgart y Ricardo René Haidar por Montoneros. De ellos, sólo Camps, Berger y Haidar lograron sobrevivir a la masacre de Trelew del 22 de agosto de 1972 que se produjo tras la fuga del 15 del mismo mes.
} 
niveles de conciencia y va convirtiéndose en dirección del Movimiento.

(FAR y Montoneros, 1972, el subrayado es nuestro) ${ }^{12}$.

Dentro de la perspectiva esbozada, en que las elecciones terminaron por aceptarse como una táctica al servicio de la creación del Ejército popular y las FAR reivindicaban abiertamente su autonomía dejando entrever sus apuestas hegemónicas, resulta comprensible que nunca asumieran para sí el rol de "formaciones especiales" que les adjudicaba Perón. Es decir, la idea de que constituían un simple instrumento táctico al servicio de una estrategia más amplia que no controlaban; una fuerza armada que, así como podía ser útil en una coyuntura determinada, también podía ser desactivada si el proyecto del general lo demandaba. De hecho, los testimonios rechazan usualmente esa denominación como "una cosa de Perón" (entrevista a "Militante de FAR 1"). Al mismo tiempo, como ya hemos mostrado, si bien las FAR desplegaron en este período una política tendiente a "articularse" con "organizaciones de base" y a insertarse territorialmente en distintas Unidades Básicas, no por ello dejaron de realizar acciones armadas, ni consideraron que aquellas debían supeditarse a una apertura electoral que, en definitiva, no era su objetivo estratégico. Pero, además, dichas acciones, sobre todo las de mayor resonancia pública, como la "ejecución” del General Juan Carlos Sánchez realizada junto con el PRT-ERP en abril de 1972, la propia fuga del penal de Rawson en agosto y otras que mencionaremos después, constituían una demostración de poder cuyo destinatario no era sólo la dictadura. Por esa vía, las FAR también buscaban posicionarse en la puja interna del movimiento e imponerse como un actor con el cual Perón tuviera que contar. Así ilustra el siguiente testimonio la lógica de accionar de la organización durante esos meses:

Yo me acuerdo que teníamos una discusión con Montoneros porque planteaban que en la etapa de la campaña electoral había que bajar el nivel de la acción militar y nosotros decíamos lo contrario. Ese fue el motivo por el que Montoneros no se integra como organización a la fuga de Rawson. Y lo que nosotros hacíamos era lo contrario, me acuerdo que el ejemplo que usábamos era la guerra de Vietnam y las negociaciones en Ginebra. Cuantas más acciones armadas hacés, más capacidad de negociación tenés...

P: ¿Tiene Perón, por ejemplo, para volver?

$\mathrm{R}$ : No, tenemos nosotros.

P: Ah, claro... ustedes... para posicionarse, negociar su presencia en esa estrategia, entiendo.

R: Esa era la idea, que no era la de Montoneros. Montoneros era más de un respeto a lo que Perón planteaba. (Entrevista a Lewinger, el subrayado es nuestro).

La "metáfora vietnamita" había sido utilizada por el propio Perón un año atrás, cuando afirmaba que la "vía de la lucha armada [era] imprescindible". Por entonces,

\footnotetext{
${ }^{12}$ Como mencionamos, las consideraciones del "Balido" intentaban fijar acuerdos entre FAR y Montoneros como aporte para la fusión entre ambas organizaciones. Allí, se proponía que el futuro Ejército popular que buscaban gestar se denominara "Ejército Peronista Montonero".
} 
sostenía que con sus acciones las organizaciones armadas: "patean para nuestro lado la mesa de las negociaciones y fortalecen la posición de los que buscan una salida electoral limpia y clara". Y advertía que "sin los guerrilleros del Viet Cong atacando sin descanso en la selva, la delegación vietnamita en París [habría tenido] que hacer las valijas y volverse a casa" (Anzorena, 1988: 174). De ese modo, el general avalaba el accionar de las "formaciones especiales", aunque también evidenciaba el uso instrumental que les daba en su estrategia. A su vez, si con el correr de los meses se volvía cada vez más claro que Perón instrumentaba a la guerrilla al servicio de la estrategia electoral, el testimonio citado muestra que las FAR le otorgaban a la "metáfora vietnamita" un sentido muy distinto del que le había dado Perón.

En definitiva, lo que las FAR buscaban mediante las diversas líneas de acción que hemos esbozado era consolidar las fuerzas propias para posicionarse como un actor con el cual la estrategia de Perón tuviera que contar y avanzar en la tarea de hegemonizar el movimiento.

\section{La campaña electoral y el progresivo acercamiento a Montoneros}

Tras 17 años de exilio, en noviembre Perón retornó al país. Había anunciado en tono conciliador que volvía en son de paz, para garantizar la reconciliación de todos los argentinos. Sin embargo, entre tanto Héctor Cámpora, su delegado personal y vicepresidente del PJ, estrechaba filas con la juventud y se hacía presente en las manifestaciones de la JP Regionales, donde se aclamaba a las organizaciones armadas en las que varios de los dirigentes juveniles ya se habían encuadrado. Por su parte, las FAR, como también otros sectores del movimiento, preveían el lanzamiento de una insurrección si la dictadura no dejaba ingresar al país al general, lo cual evidentemente no tuvo lugar ya que el 17 de noviembre Perón aterrizó en Ezeiza ${ }^{13}$. Una multitud se movilizó para recibirlo, pero un fuerte dispositivo de seguridad frustró el intento y el general se dirigió a la residencia de la calle Gaspar Campos, en Vicente López, donde tenía previsto instalarse. Durante varios días desfilaron por allí enormes columnas de la JP, al tiempo que el general organizó un encuentro con la dirigencia de las organizaciones armadas al que concurrió Arturo Lewinger en nombre de las $\mathrm{FAR}^{14}$. A su vez, en plenas tratativas electorales, Perón

\footnotetext{
${ }^{13}$ Previendo que la dictadura impediría su llegada, las FAR distribuyeron una serie de instrucciones que indicaban tomar barrios y fábricas, cortar rutas, acopiar elementos para armar barricadas, etc. (FAR, 1972c). De hecho, un miembro de la organización recuerda haber participado de esos preparativos en la zona de Morón (entrevista a "Militante de FAR 1"). A su vez, Elvio Alberione relata que se preparaba un alzamiento de militares peronistas si esa eventualidad tenía lugar. En la ESMA, los preparativos fueron descubiertos antes de tiempo, lo que precipitó una sublevación al mando del teniente Julio César Urien que reunió a unos 80 hombres, en su mayoría suboficiales (Chaves y Lewinger, 1998: 141-145).

${ }^{14}$ Según Gasparini (2008: 48-49), al salir de la reunión Arturo Lewinger manifestó entusiasmado que todo marchaba "a las mil maravillas", acotando: "fue emocionante, hasta me acarició la cabeza". Se desconoce el contenido del encuentro, aunque el relato sugiere que fue alentador para los grupos armados. Aun así, la candidez de las palabras de Lewinger parece sorprendente en relación con los planteos de las FAR que hemos analizado. Sin embargo, están a tono con algunas anécdotas relatadas por su hermano Jorge en una semblanza que realizó en ocasión de su muerte (S/d. autor, 1975). Allí relató que durante las encarnizadas discusiones que antecedieron a la peronización de las FAR, Arturo llegó afirmar que
} 
se reunió con la dirigencia de diversos partidos políticos, entre ellos antiguos adversarios como Ricardo Balbín.

Tras un mes de estadía en el país, el general partió nuevamente no sin antes realizar dos movimientos claves: constituir el FREJULI, un frente electoral que además del peronismo incluía al MID, al Partido Popular Cristiano, Conservador Popular y a una rama del socialismo liderada por Jorge Selser, y nombrar a Cámpora como candidato presidencial. El peronismo concurriría a elecciones, pero el candidato no sería su líder. La designación, que fue apoyada por la JP, Montoneros y FAR, generó las resistencias del aparato sindical encabezado por Rucci y Rogelio Coria, quienes, tras haber propuesto a Antonio Cafiero, ahora amenazaban con no aceptar otra candidatura que la de Perón. Pese a todo, apenas un día después de la partida del general, el Congreso del PJ proclamaba la fórmula "Cámpora-Solano Lima" que luego sería adoptada por el FREJULI.

A fines de enero de 1973 se lanzó oficialmente la campaña electoral del nuevo Frente, signada por una dinámica de creciente movilización, radicalización política y consignas desafiantes, y donde la juventud, Montoneros y FAR tuvieron una presencia protagónica pegando afiches, realizando pintadas, abriendo Unidades Básicas y organizando manifestaciones. Tras la designación del candidato del FREJULI, la JP había acuñado la conocida consigna "Cámpora al gobierno, Perón al poder". FAR y Montoneros consensuaron otra que también adquirió gran predicamento entre la juventud: "Con el Frente ganaremos las elecciones, con el Ejército Peronista tomaremos el poder", o, en su versión reducida: “Con el Frente al gobierno y con las armas al poder" (FAR, 1973c).

La consigna expresaba de modo diáfano la postura de las FAR, tanto la lógica instrumental que guió su accionar durante la coyuntura electoral, como la tensión entre la lógica democrático institucional y la lógica revolucionaria que según Lenci (1999) signaba las apuestas de buena parte de la tendencia revolucionaria del peronismo. En sus comunicados, las FAR reafirmaban que con las elecciones se ganaría "una batalla, pero no la guerra" y que los comicios y el gobierno popular resultante serían "avances importantes para el campo popular" pero que el objetivo final era la "toma del poder". La historia del peronismo mostraba que si el pueblo no estaba organizado y armado esos avances populares serían desconocidos por los “dueños del poder económico y militar". En definitiva, aclaraban, en esta etapa lo fundamental era la movilización y organización de las masas en función de la construcción del instrumento que permitiría la toma del poder: "el Ejército Peronista como fuerza hegemónica del campo popular" (FAR, 1973b, c y d). Dichas consideraciones eran compartidas por Montoneros, al punto que, al calor de un trabajo político cada vez más mancomunado, un informe interno de las FAR llamaba a sus militantes a firmar con las siglas de ambas organizaciones todos sus panfletos de campaña (FAR, 1973a). Poco después, los planteos señalados fueron rubricados en un comunicado conjunto (FAR y Montoneros, 1973a).

\footnotetext{
"Perón era bueno" para convencer a sus compañeros. Por otra parte, se sabe que por esos meses el general también se reunió en Europa con dirigentes de las organizaciones armadas, entre ellos Roberto Quieto, quien todavía no había vuelto al país tras la fuga de Rawson (Anzorena, 1988 y Gasparini, 2008).
} 
Ahora bien, la dinámica política de esos meses no estuvo signada sólo por la radicalización de las consignas de campaña. En el caso de las FAR, el 28 de diciembre habían matado al contralmirante recientemente retirado Emilio Berisso, a quien responsabilizaban por la masacre de Trelew (FAR, 1972d) ${ }^{15}$. Tras esos hechos, Perón abandonó el tono pacificador que lo había caracterizado durante su estadía en el país y declaró ante la prensa que "si tuviera 50 años menos, no sería incomprensible que anduviera ahora colocando bombas o tomando justicia por mano propia" (Anzorena, 1988: 229). Días después, en un conocido reportaje para la revista Mayoría, retomó su discurso confrontativo. Allí declaraba que los militares eran una "banda de gangsters", avalaba la consigna "Cámpora al gobierno, Perón al poder" y advertía: "o la juventud toma esto en sus manos y lo arregla, aunque sea a las patadas, pero lo arregla, o no se lo va arreglar nadie". Como era usual, en el mismo reportaje atemperaba esas palabras afirmando el valor de las elecciones, un terreno donde sostenía tener el triunfo asegurado. En ese sentido, aunque sin abandonar el tono amenazante, declaraba: "Se lo he dicho a los muchachos y los muchachos se han parado, porque estaban para más" (Bonasso, 1997: 352-353). Con todo, las acciones armadas continuaron. El 22 de enero las FAR se adjudicaron la muerte de Julián Moreno, secretario adjunto de la UOM de Avellaneda, debido a que junto con parte de su gremio había desobedecido las órdenes de Perón respecto de las candidaturas del FREJULI en Buenos Aires. En la prensa circuló la versión de que el hecho respondía a una interna sindical y que el comunicado era falso. En este caso, Perón se hizo eco de los rumores y declaró que consideraba apócrifa la firma de "esa formación especial", atribuyendo el atentado a "provocadores"16.

Entre tanto, las iniciativas de la dictadura de Lanusse no hacían más que envolver a todos los protagonistas en un clima de desconcierto e incertidumbre (De Riz, 1989: 51). Durante esos meses, la Cámara Federal en lo Penal denunciaba a Perón por incitación a la violencia, la Junta de Comandantes amenazaba con proscribir al FREUJLI por la consigna "Cámpora al gobierno, Perón al poder" y prohibía el retorno del general antes de las elecciones. Todo ello acrecentaba los rumores sobre la efectiva concreción de los comicios y contribuía al discurso confrontativo del peronismo y de su líder, quien no dudaba en afirmar que el movimiento estaba preparado "para otras cosas además de votar" (Gillespi, 1998: 137).

\footnotetext{
${ }^{15}$ Clarín, 29/12/72. Berisso había sido asesor de la delegación militar argentina en la Junta Interamericana de Defensa en Washington. Además, desde febrero de 1971 y hasta su reciente retiro, había ocupado el cargo de Jefe de Política y Estrategia del Estado Mayor General Naval.

${ }^{16}$ Sobre el hecho $L N$ y Crónica, 23/1/73. En diciembre, Luis Guerrero, secretario general de la UOM de Avellaneda, también había sufrido un atentado, en su caso frustrado, que Bonasso (1997: 370) le atribuye a las FAR y Gillespi (1998: 154) a Montoneros. Tiempo antes, Guerrero se había postulado a vice de Manuel Anchorena -un acaudalado terrateniente peronista de derechas- para la gobernación de Buenos Aires, contrariando las instrucciones de Perón respecto de tales candidaturas. Poco después, ante la oposición generada al interior del movimiento, ambos tuvieron que desistir de su empeño. Julián Moreno, muerto junto a su chofer Argentino Deheza, también había formado parte de la maniobra, por lo que el comunicado de las FAR (1973e) lo acusaba de "traidor a Perón”. A primera vista, el escrito no parece apócrifo. En cualquier caso, la muerte de Moreno, incorporada a la lista de "traidores al pueblo y a Perón" alcanzados por la "justicia popular", fue reivindicada por las FAR en comunicados posteriores.
} 
Mora González, ¿Democracia y/o Revolución? Las Fuerzas Armadas Revolucionarias frente a la coyuntura electoral: los comicios, la revolución y la lógica instrumental (Argentina, 1972-1973), Izquierdas, 38, febrero 2018:164-189

Pese a todo, las elecciones finalmente tuvieron lugar y el 11 de marzo de 1973 el FREJULI triunfó con el 49,6\% de los votos, frente al 21,3\% de la UCR que quedó en segundo lugar.

Como mencionamos, siguiendo la lógica de consolidar las fuerzas propias, durante la campaña electoral las FAR trabajaron de modo cada vez más estrecho junto a Montoneros, una tendencia que se consolidará tras los comicios. Ese acercamiento había tenido su puntapié inicial el año anterior, sobre todo tras la frustración de las OAP, el alejamiento de las FAR de la propuesta "alternativista" de un sector de las FAP y los acuerdos establecidos en Rawson con algunos dirigentes montoneros. Tal como señalamos, esos meses de 1972 fueron claves en términos de la reorientación de los planteos de las FAR ya que se acercaron cada vez más a la postura "tendencista" de Montoneros. Aun así, persistían algunas diferencias donde se perciben ciertas huellas de origen de las previas posiciones de las FAR. Una de ellas, que ya hemos mencionado, era su distinta valoración del liderazgo de Perón, que las FAR consideraban un "líder popular" y la mayor parte de la dirigencia montonera un "líder revolucionario". La otra tiene que ver con la forma de caracterizar la "contradicción principal" del país en la nueva etapa que se abría y puede rastrearse en algunos documentos que ambas organizaciones intercambiaron por entonces, ya con vistas a su fusión (Montoneros, 1973; FAR, 1973f). Montoneros definía tal contradicción principal bajo los términos "Nación-Imperialismo". Por su parte, las FAR acordaban en que dicha formulación permitía visualizar la característica esencial del país que era su dependencia, pero requerían que se explicitara claramente las clases y sectores que integraban cada uno de esos campos antagónicos. Según su visión, el riesgo de aquella formulación era no subrayar lo suficiente que el imperialismo había penetrado en la estructura económica argentina y, por lo tanto, concebir como enemigo sólo al capital extranjero. De allí que las FAR sugirieran a Montoneros precisar la formulación de esa contradicción aclarando que la misma enfrentaba a la alianza constituida por el imperialismo y la oligarquía nativa (donde incluían a la alta burguesía industrial, financiera, comercial y agropecuaria) con la clase obrera, demás sectores populares y la mediana burguesía urbana y rural. Como señalamos, a diferencia de sus planteos de 1971, ahora las FAR sí consideraban viable la convergencia con la mediana burguesía durante cierto tramo del proceso de liberación nacional y social que impulsaban. Según aclaraban, la etapa abierta tras los comicios no estaba signada por una política "antiburguesa", sino "antiimperialista, antimonopólica y antioligárgica, como primer paso en la transición al socialismo". Por tanto, en esa etapa, las contradicciones de la clase obrera con la mediana burguesía eran de carácter secundario (FAR, 1973f: 617-623).

Para finalizar, apuntemos que si bien el "Acta de Unidad" fue fechada el 12 de octubre de 1973 -nada menos que el día en que Perón asumió su tercera presidencia- (FAR y Montoneros, 1973f), el proceso de convergencia había sido puesto en marcha meses atrás. En realidad, de acuerdo al testimonio de Perdía, la decisión de fusionar ambas organizaciones bajo el nombre Montoneros fue tomada de modo contemporáneo a la victoria electoral (Perdía, 1997: 179-180). De hecho, a partir de entonces sus principales declaraciones públicas se realizaron de modo conjunto (FAR y Montoneros, 1973a, b, c, d y 
e) y las agrupaciones de activistas con que ambas se habían ligado fueron convergiendo en los "frentes de masas" que se crearon por entonces. Entre los más importantes estuvieron la "Unión de Estudiantes Secundarios" (UES), la "Juventud Universitaria Peronista" (JUP) y la "Juventud Trabajadora Peronista" (JTP), lanzadas entre abril y mayo de ese año.

A su vez, según el relato de Perdía, dada la dificultad que entrañaba unificar las estructuras que FAR y Montoneros habían desarrollado a lo largo del país, lo primero que se hizo fue constituir la nueva conducción nacional, que sería la encargada de dirigir el resto del proceso. Para entonces, Montoneros era una organización mucho más numerosa que las FAR. Se había fusionado con Descamisados a fines de 1972 y, sobre todo, había crecido exponencialmente gracias a sus ligazones con variadas agrupaciones de activistas, principalmente con la JP. Lo cual, se evidenció tanto en el nombre adoptado, como en la composición de la nueva conducción nacional y en el reparto de todos los cargos intermedios de la organización unificada. De acuerdo a Perdía, la conducción nacional quedó integrada por 8 miembros, 5 de Montoneros y 3 de las FAR, al tiempo que los dos primeros puestos de esa estructura correspondieron a la primera organización, donde Roberto Quieto ocupaba recién el tercer lugar ${ }^{17}$. Según se convino, dichas proporciones (5 a 3) luego fueron utilizadas como factor de "corrección política" en la distribución de los puestos de conducción intermedia en los distintos ámbitos militantes que debían unificarse. Un proceso que, según Flaskamp (2002), no estuvo exento de fuertes fricciones.

No existen investigaciones que indiquen si esa fusión tuvo algún peso específico en la dinámica posterior de Montoneros, y las memorias sobre la cuestión son disímiles. Nuestros entrevistados afirman haber considerado estratégica la convergencia, pese a que buena parte de ellos reivindica su previa filiación con las FAR por sus posiciones menos "movimientistas" y "más de izquierda". En cualquier caso, ninguno sostiene que las derivas posteriores de Montoneros se hayan debido a la fusión. Por su parte, los testimonios de algunos ex dirigentes montoneros tienden a atribuir las posiciones que hoy consideran erradas a las tendencias "militaristas" y de mayor afinidad con la izquierda de las FAR (Perdía, 1997 y Amorín, 2005). La dinámica de esa nueva organización fusionada durante el período democrático abierto en 1973 forma parte de otra historia.

\section{Palabras finales}

Hacia 1972, la apertura electoral impulsada por Lanusse y la estrategia de Perón, quien buscaba reorganizar el propio movimiento y ampliar sus alianzas políticas y sociales,

\footnotetext{
${ }^{17}$ Según Perdía (1997: 180), la conducción nacional se constituyó del siguiente modo: 1- Mario Eduardo Firmenich (Montoneros); 2- Roberto Cirilo Perdía (Montoneros); 3- Roberto Quieto (FAR); 4- Carlos Alberto Hobert (Montoneros); 5- Raúl Clemente Yäguer (Montoneros); 6- Julio Roqué (FAR); 7- Horacio Mendizábal (incorporado a Montoneros tras su fusión con Descamisados) y 8- Marcos Osatinsky (FAR). Gasparini (2008: 142) brinda en este punto un testimonio divergente. Apunta que, en realidad, Roberto Quieto ocupaba el $2^{\circ}$ lugar en la conducción nacional, del que habría sido despromovido al $3^{\circ}$ recién en 1975 , el año en que lo mataron. Según su relato, por entonces Quieto había solicitado alejarse de la conducción nacional por diferencias políticas -que no especifica- y problemas personales, pedido que fue rechazado por sus pares, quienes lo despromovieron por ello.
} 
Mora González, ¿Democracia y/o Revolución? Las Fuerzas Armadas Revolucionarias frente a la coyuntura electoral: los comicios, la revolución y la lógica instrumental (Argentina, 1972-1973), Izquierdas, 38, febrero 2018:164-189

impusieron a las organizaciones armadas peronistas uno de sus mayores desafíos: cómo ampliar sus bases de sustentación para evitar la situación de aislamiento a la que parecía conducirlas la nueva coyuntura.

A lo largo de este trabajo hemos reconstruido las prácticas y discursos de las FAR buscando analizar la estrategia que trazaron frente a tal encrucijada política, los cambios que esa estrategia implicaba respecto de sus posturas previas y los sentidos que le atribuyeron a su apoyo a la compaña electoral del peronismo.

Como hemos evidenciado, las FAR esbozaron tres líneas de acción con el objetivo de consolidar las fuerzas propias y reposicionarse en la nueva coyuntura: 1) continuar con la realización de acciones armadas, 2) avanzar en la convergencia con otras organizaciones armadas peronistas y 3) consolidar vínculos más orgánicos con sectores combativos del movimiento popular. A ellas se sumaron otras reorientaciones, como sus nuevas consideraciones sobre el rol de la mediana burguesía en el proceso de liberación, esbozadas en el marco del esquema de alianzas de clases impulsado por Perón, y su cambio de política frente a las "estructuras formales" del peronismo, en una coyuntura signada por la reorganización del movimiento. Todo ello debilitaba, aunque sin borrar completamente, las dos huellas de origen que hasta entonces le habían otorgado a las FAR su impronta distintiva: la huella marxista y la huella guevarista. Al mismo tiempo, las acercaba a la postura "tendencista" de Montoneros, organización con la que se fusionarían poco después.

Particularmente en sintonía con la tercera línea de acción señalada debe ubicarse la decisión de las FAR de apoyar la participación del peronismo en los comicios de marzo de 1973. Siguiendo una estricta lógica instrumental que el propio Perón había sabido alentar, ni las elecciones ni el futuro gobierno democrático fueron concebidos como un fín en sí mismo, sino como medios para otros fines. Es decir, como un paso táctico en el marco de una estrategia revolucionaria más amplia: construir el Ejército del pueblo que condujera finalmente al socialismo. De la propia afirmación se desprenden varias cuestiones distintas. En principio, no se trata de la "vía chilena" al socialismo, la convicción de las FAR es que para dejar atrás al capitalismo es indispensable la construcción de un Ejército que libre una guerra popular y prolongada. Sí existe la apuesta de radicalizar el futuro gobierno popular hasta desencadenar un proceso de liberación nacional pero también social. Y la certeza de que dicho tránsito no podrá garantizarse sin el respaldo de un poder armado que paralelamente habrá que construir y que finalmente terminará conduciendo el proceso. No es difícil percibir la tensión entre la legitimidad democrático-institucional y la legitimidad revolucionaria yuxtapuestas en esa apuesta, que no tardarían en estallar como contradicción durante los futuros gobiernos peronistas, sobre todo al ritmo del desencuentro con los planes de Perón y del aumento de la represión. De todos modos, para el caso específico de las FAR no creemos que dicha tensión deba interpretarse como una opción dicotómica (asimilable, a su vez, a la que existiría entre la lógica de la política y la lógica de la guerra), como sugiere Lenci (1999) para el espectro más amplio y heterogéneo de la tendencia revolucionaria del peronismo. En principio, porque en el caso de las FAR no existió una verdadera opción entre ambas lógicas, sino que una fue pensada como un medio en función 
Mora González, ¿Democracia y/o Revolución? Las Fuerzas Armadas Revolucionarias frente a la coyuntura electoral: los comicios, la revolución y la lógica instrumental (Argentina, 1972-1973), Izquierdas, 38, febrero 2018:164-189

de la otra. Y, además, porque para las FAR el lenguaje bélico fue una de las formas de su política que, como tal, siempre fue una política armada.

Para finalizar, resta subrayar que, reponiendo tanto sus fines como el carácter estratégico de su accionar -y por esa vía, su capacidad de agencia en tanto actor político-, hemos buscado evidenciar que a través de todas las reorientaciones señaladas las FAR buscaban consolidar la organización de modo de evitar el aislamiento, posicionarse como un actor con el cual la estrategia de Perón tuviera que contar y avanzar en la tarea de hegemonizar el movimiento peronista.

\section{Bibliografía y fuentes}

Amorín, José, Montoneros. La buena historia, Buenos Aires, Catálogos, 2005. Anzorena, Oscar, Tiempo de violencia y utopía (1966-1976), Buenos Aires, Contrapunto, 1988.

Bonasso, Miguel, El presidente que no fue, Buenos Aires, Planeta, 1997.

Bozza, Alberto, "Las artes del asedio y la negociación. Perón y el lanzamiento del Frente Cívico de Liberación Nacional", en Pucciarelli, Alfredo (ed.), La primacía de la política. Lanusse, Perón y la Nueva Izquierda en tiempos del GAN, Buenos Aires, Eudeba, 1999.

Barletta, Ana, Lenci, Laura y Ramírez, Ana Julia, "Democracias en pugna: un intento de recuperar los sentidos perdidos", Cuestiones de Sociología, No 9, La Plata, 2013.

Chaves, Gonzalo y Lewinger, Jorge Omar, Los del 73, La Plata, De la Campana, 1998.

De Amézola, Gonzalo, Levingston y Lanusse o el arte de lo imposible, Buenos Aires, Al Margen, 2000.

De Riz, Liliana. (1981), Retorno y Derrumbe, Buenos Aires, Folios Ediciones, 1981.

Flaskamp, Carlos, Organizaciones político militares. Testimonio de la lucha armada en la Argentina (1968-1976), Buenos Aires, Ediciones Nuevos Tiempos, 2002.

Fuerzas Armadas Revolucionarias, "Los de Garín", Cristianismo y Revolución, No 28, Buenos Aires, 1971a.

"13 preguntas a las FAR", Nuevo Hombre, № 17, Buenos Aires, $1971 b$.

- "Nuestra respuesta elaborada por el compañero Olmedo", Militancia, No 4, Buenos Aires, [1971]1973.

[Regional Córdoba], "El combate de Fiat", s/f. [1971], en Legajo No 641, "Opereta Corina", Carpeta Bélico, Mesa DS, Archivo de la Dirección de Inteligencia de la Policía de la Provincia de Buenos Aires (DIPBA), bajo custodia de la Comisión Provincial por la Memoria (CPM), La Plata. "Documento de actualización política", 1972a, en Legajo No 641, op. cit.

__ Boletín $\mathrm{N}^{\circ} 4$, s/d. editorial ni lugar, 1972b.

"Orientaciones para proteger las movilizaciones", 1972c, en Amato, Fernando y Boyanovsky Bazán, Cristian, Setentistas, Buenos Aires, Sudamericana, 2008.

“¡Leña a los gorilas asesinos y vendepatria!", 1972d, en Legajo $\mathrm{N}^{\circ}$ 626, "Homicidio del

Contraalmirante xx, Jefe del Comando Político y Estratégico de la Armada en Lomas de Zamora 1ra el 28-12-72", Carpeta Varios, Mesa DS, Archivo DIPBA, CPM.

Comando Eva Perón, “A nuestro Pueblo. Dock Sur”, 1972, en Legajo No 641, op. cit. "Informe interno", 1973a. En Legajo No 641, op. cit. 
Mora González, ¿Democracia y/o Revolución? Las Fuerzas Armadas Revolucionarias frente a la coyuntura electoral: los comicios, la revolución y la lógica instrumental (Argentina, 1972-1973), Izquierdas, 38, febrero 2018:164-189

"Con el frente al gobierno, con el Ejército Peronista al poder", 1973b, Punto Final, No 184, Santiago, 1973.

“Cámpora al gobierno, Perón al poder", 1973c, en Legajo No 641, op. cit.

"A nuestro pueblo. Buenos Aires, 1 de abril de 1973", 1973d, en Legajo N ${ }^{\circ}$ 718, "Toma del edificio central de Tribunales grupo FAR en San Isidro", Mesa DS, Archivo DIPBA, CPM.

"A nuestro pueblo", 1973e, en Legajo No 641, op. cit.

"Aportes críticos de las Fuerzas Armadas Revolucionarias al "Documento Base para la Reactualización de la Línea Político-Militar 1973f, en Baschetti, Roberto, De la guerrilla peronista al gobierno popular. Documentos 1970-1973, Buenos Aires, De la Campana, 1997.

FAR y Montoneros, "Opiniones sobre los problemas centrales de la guerra revolucionaria en esta etapa", FAR, Boletín No 4, s/ d. editorial ni lugar, 1972.

"Al pueblo de la patria, 24 de mayo de 1973", 1973a. Disponible en Centro de documentación de las organizaciones político-militares argentina "El topo blindado": http://eltopoblindado.com/.

"Construir poder popular", Militancia, No 1, Buenos Aires, 1973b.

"Defender la victoria", Militancia, No 2, Buenos Aires, 1973c.

"Perón enfrenta a la conspiración", El Descamisado, № 9, Buenos Aires, 1973d.

"Los yanquis son los mayores enemigos de nuestro pueblo", El Descamisado, No 193, Buenos Aires, 1973e.

"Acta de la unidad", Militancia, No 19, Buenos Aires, 1973f.

Gasparini, Juan, Montoneros: final de Cuentas, La Plata, De la campana, 2008.

Gillespi, Richard, Soldados de Perón. Los Montoneros, Buenos Aires, Grijalbo, 1998.

González Canosa, Mora, "Los pasos perdidos. Acerca del itinerario político-ideológico de uno de los grupos fundadores de las FAR (1960-1966)", Cuestiones de Sociología, No 7, La Plata, 2011.

"Modelo para armar. Itinerarios y ámbitos disidentes del Partido Comunista en la formación de uno de los grupos fundadores de las FAR (1960-1967)", Izquierdas, No 12, Santiago de Chile, 2012.

Las Fuerzas Armadas Revolucionarias. Orígenes y desarrollo de una particular conjunción entre marxismo, peronismo y lucha armada (1960-1973). Tesis de Doctorado inédita. Doctorado en Ciencias Sociales. Universidad de La Plata, La Plata, 2013a. Disponible en: http://www.memoria.fahce.unlp.edu.ar/tesis/te.808/te.808.pdf

"Un sendero guevarista: pervivencias y torsiones en los orígenes de las Fuerzas Armadas Revolucionarias", Izquierdas, $\mathrm{N}^{\mathrm{o}}$ 15, Santiago de Chile, $2013 \mathrm{~b}$.

"Políticas de construcción del peronismo. El discurso de las FAR en los albores de la década del setenta en Argentina", Tempo e Argumento, No 14, Florianópolis, 2015.

"La política armada. La lógica de las prácticas políticas de las FAR y el problema de la relación con las masas durante los primeros años de la organización", en Pittaluga, Roberto (comp.), Formas de la política. Experiencias de activismo en el pasado reciente. Argentina (1969-2010), La Pampa, EdUNLPalm, 2016 (en prensa).

Lanusse, Lucas, Montoneros. El mito de sus doce fundadores, Buenos Aires, Vergara, 2005

Lenci, Laura, "Campo al Gobierno, Perón al Poder. La tendencia revolucionaria del peronismo ante las elecciones del 11 de marzo de 1973”, en Pucciarelli Alfredo (ed.), La primacía de la política. Lanusse, Perón y la Nueva Izquierda en tiempos del GAN, Buenos Aires, Eudeba, 1999.

Montoneros, "Boletín Interno No 2. Primera quincena de mayo", 1973, en Baschetti, Roberto, De la guerrilla peronista al gobierno popular. Documentos 1970-1973, Buenos Aires, De la Campana, 1997.

Ollier, María Matilde, Orden, poder y violencia (1968-1973), Buenos Aires, CEAL, 1989.

Perdía, Roberto, La otra historia: testimonio de un jefe montonero, Buenos Aires, Grupo Ágora, 
Mora González, ¿Democracia y/o Revolución? Las Fuerzas Armadas Revolucionarias frente a la coyuntura electoral: los comicios, la revolución y la lógica instrumental (Argentina, 1972-1973), Izquierdas, 38, febrero 2018:164-189

1997.

Pozzoni, Mariana, "La Tendencia Revolucionaria del peronismo en la apertura política. Provincia de Buenos Aires, 1971-1974”, Estudios Sociales, N 36, 2009.

Raimundo, Marcelo "Izquierda peronista, clase obrera y violencia armada: Una experiencia alternativa", Sociohistórica, № 5-16, La Plata, 2004.

S/d. autor, "Oficial superior Arturo Lewinger caído en acción", Evita Montonera, № 5, Buenos Aires, 1975.

Vaca Narvaja, Gustavo y Frugoni, Fernando, Fernando Vaca Narvaja, con igual ánimo, Buenos Aires, Colihue, 2002.

Entrevistas realizadas por la autora

Carlos Flaskamp, Buenos Aires, 28 de diciembre de 2007 y 20 de diciembre de 2011.

Jorge Omar Lewinger, Buenos Aires, 27 de diciembre de 2007 y 15 y 27 diciembre 2011.

José Miguel Candia, La Plata, 10 de septiembre de 2012 y 2 de diciembre de 2015.

Mercedes Inés Carazo, intercambio electrónico Buenos Aires/Perú, marzo-abril de 2012

"Militante de FAR 1", Buenos Aires, 11 de enero de 2012.

"Militante de FAR 2", Buenos Aires, 6 de marzo de 2012.

Nora Patrich, Buenos Aires, 12 de abril de 2012.

Ricardo Rodrigo, intercambio electrónico Buenos Aires/España, enero-marzo de 2012.

Sara Solarz (dos sesiones vía skype), Buenos Aires / Suiza, 4 y 11 de abril de 2012. 